\title{
An Analysis of Code Switching Used by Lecturer of English Education Department at Ganesha University of Education
}

\author{
w suarnajaya@yahoo.comasrilmardjohan@gmail.com \\ punyadanu@yahoo.co.id \\ Danu Wijaya \\ 1012021138 \\ English Education Department, Language and Art Faculty \\ Ganesha University of Education \\ Singaraja, Indonesia
}

\begin{abstract}
Abstrak
Penelitian ini bertujuan untuk menganalisis tipedari alih kodebahasa, fungsi alih kodebahasa, dan alasan penggunaan alihkodebahasa yang digunakanoleh dosen bahasa Inggris sebagai strategi komunikasi untuk mengajar bahasa Inggris sebagai bahasa asing di semester II Jurusan PendidikanBahasa Inggris di Universitas Pendidikan Ganesha.Penelitian ini merupakan penelitian deskriptif kualitatif. Subjek penelitian ini adalah dosen laki-laki. Instrumen yang digunakan dalam penelitian ini adalah perekam MP3, catatan lapangan, dan panduan wawancara. Hasil penelitian ini menunjukkan bahwa ada dua jenis alih kode yang digunakan oleh guru bahasa Inggris. Mereka adalah intra-sentential alih kodebahasa (52\%) dan inter sentensial alih kodebahasa (48\%). Ada tujuh fungsi alihkode bahasa yang digunakan oleh dosen bahasa Inggris; fungsi klarifikasi (36\%), fungsi penekanan (29\%), fungsi perhatian (12\%), fungsi instruksi (9\%), fungsi kebutuhanbahasa (8\%), fungsi regulasi (3\%) dan fungsi hiburan (3\%). Alasan penggunaan alih kode bahasa adalahuntukmembicarakan topik tertentu, menegaskansesuatu, pengulangan yang digunakan untuk klarifikasi, maksud untukmenjelaskan isi pembicaraanpadapendengar, meningkatkan motivasi dalam belajar bahasa Inggris, membantu siswa untuk menangkap informasi yang diberikan oleh pengajar, menciptakan suasana yang menyenangkan belajar, dan memberikan perintah atau instruksi
\end{abstract}

Kata Kunci : AlihKodeBahasa, BahasalnggrisSebagaiBahasaAsing, DosenBahasalnggris, StrategiKomunikasi

\section{Abstract}

This study aimed at analyzing the types of code switching, the functions of code switching, and the reasons of using code switching by English lecturer as a communication strategy to teach English as a foreign language in the second semester of English Education Department at Ganesha University of Education. This study is a descriptive qualitative research. The subject of this study is a male lecturer. The instruments used in this study are MP3 recorder, a field note, and an interview guide. The results of this study show that there are two types of code switching used by the English lecturer. They are intra-sentential code switching (52\%) and inter sentential code switching (48\%). There are seven functions of code switching used by the English lecturer namely; clarification functions $(36 \%)$, emphasis function $(29 \%)$, attention function $(12 \%)$, instruction function $(9 \%)$, lexicalization function ( $8 \%$ ), regulatory function (3\%) and sociolinguistic play function (3\%). The reasons of using code switching are talking about particular topic, being emphatic about something, repetition used for clarification, intention of the speech content for the interlocutor, increasing motivation in learning English, helping students to catch the information given by the lecturer, creating a fun learning atmosphere, and giving command or instruction

Key Words $\quad$ : Code Switching, Communication Strategy, English as Foreign Language, English

Lecturer 


\section{INTRODUCTION}

Language is a means of communication which is effective in conveying something. In daily life, people use language to communicate with other people: friends, family, or stranger. For bilingual people, in a process of communication they do not only use one kind of language, it can be more than one language. It is because they master more than one language and they apply it in a communication through switching the language. Cook (2000) provides another straightforward explanation which denotes code-switching as a process of going from one language to another in the midst of a conversation, where both parties can understand the same languages.

Phenomenon of switching the language can occur either in formal or non formal communication. In relation with formal situation, especially in education domain, the implementation of bilingual can be showed by most of Indonesian schools or universities that use Indonesian as a language transfer when teaching English. It is done by regarding the assumption that students will get difficulties to understand the lesson if the teacher merely focus on using monolingual language which is not their native language. Meanwhile, this phenomenon also occurs in teaching and learning process. This phenomenon is possibly caused the lecturer use code switching strategy as a solution in order to avoid the students to finding a difficulty in learning the material given by the lecturer

There are seven reasons why people make variations or switch their language (Hoffman, 1991). These seven reasons include; (1) Talking about a particular topic, (2) Quoting somebody else, (3) Being emphatic about something, (4) Interjection, (5) Repetition used for clarification, (6) Intention of clarifying the speech content for the interlocutor, (7) Expressing group identity.

The language becomes part of society which is able to connect to other people and the relationship between language and society is learned in a study which is called sociolinguistics. According to Holmes (in DeniNitiasih 2014), Sociolinguistics is a term that refers to the study of the relationship between language and society, and how language is used in multilingual speech communities. Sociolinguistics is a study that explains about why some people speak differently in a different context and different situation. In sociolinguistics, code switching means the use of more one language in communication. Code switching is used by many teachers and lecturers as a method to teach the students in the classroom. The use of code switching by teacher is not always performed consciously; which means that the teacher does not always realize about the functions and outcomes of the code switching process" (Sert, 2005, p. 2). The lecturer also used code switching in the classroom and the lecturer used the code switching consciously or unconsciously. The uses of code switching possibly depend on the difficulty of the topic which is being explained.

Moreover, the phenomenon of switching languages can be found in many forms, for example, in newspaper, film, novel, song, etc (Itaul, Husna, 2010). Code-switching is used to convey humor, praise, encouragement and chastising in a German as a foreign language class in Texas (Seidlitz, 2003). From Othman and Saat's (2009) survey on pre-service science teachers in Malaysia, it was also found that teachers code-switched to gain their students' attention in class. Codeswitching is also used to address personal statements to specific students (Then \& Ting, 2009). Although the use of codeswitching does not make a better explanation of the subject matter, the implementation of code switching is useful for maintaining interpersonal aspects of the teacher-student relationship to produce a more conducive environment for the teaching and learning activities

Based on the pre-observation, the English lecturer sometimes used his native language in conducting the 
teaching and learning process. The lecturer used code switching that was adjusted with students' ability and made the students able to understand the lesson easier. English Education Department uses English language as a major language, but code switching from English to Indonesian still can be found. Based on those two facts the researcher wanted to investigate what types of code switching that was used by lecturer in a higher level at university especially the English Department of which is major language is English.

In this study the researcher is interested in investigating the code switching which is used by English lecturer in teaching learning process. The researcher also wants to analyze the function of code switching that was used by the lecturer of English Education Department at Ganesha University of Education. This University is chosen by the researcher regarding to several reasons. First, Ganesha University is one of the state Universities in Singaraja and this University's outstanding department is English Education Department. As English Department, certainly English language is a common or basic language which is used as a means of communication in teaching and learning process. The researcher wants to find the code switching and the functions of code switching that was used by the lecturer of English Education Department at Ganesha University. Second, based on the researchers pre-observation on the second semester of D Class, there were few students that understood about the lecturers command and some of the students sometimes asked their friends about what the lecturer meant. This is the example of conversation between lecturer and students:

L: Do you want to learn something new or learn about something that you still not understand about? Gimana? (513)
S: (Silence)
L: Kalian maubelajar grammar yang belumdibahasataubahas yang

sudahdibahas, yang belum kalian ngerti? (514)

S: Yes sir, adausul Pak, membahastugas yang dikumpul (515)

The conversation above shows that sometimes the students do not clearly understand about the lecturer's explanation so the lecturer switches the code from English into Indonesian. The researcher is curious and wants to know the function of code switching that was used by the lecturer in teaching and learning process.

The use of code switching was not always performed consciously by the teacher. The language switched suddenly when the teacher wanted to emphasize the meaning of a particular topic because of the students' need.

Based on the theoretical background above, the researcher aims at analyzing the code switching that was used by English lecturer at university level. The title of the research is An Analysis of Code Switching Used by Lecturer in English Education Department at Ganesha University of Education. The researcher wants to investigate the types of code switching, the functions of code switching, and the reason of using code switching in the learning process. This study was conducted at D class second semester of English Education Department. The subject of this study was English lecturer of English Education Department and the object of this study was the code switching that was uttered by the lecturer

\section{RESEARCH METHOD}

In this study the researcher gathered the data by collected lecturer's utterances that were contained code switching. The data was recorded by MP 3 recorded. There also some additional notes that were used to support the data collection. In addition, the researcher also interviewed the teacher to get more information about code switching. 
The object of this study was lecturer's utterances that indicated code switching. This research focused on the code switching that had been produced by the lecturer, whether it was from English to Indonesian or vice versa. This study was analyzed of how the teacher gave commands, asked questions, explained material, discussed related material and responded to the students' answer or feed back.

In this study, the researcher observed anEnglish lecturer of Ganesha University of Education. The researcher observed lecturer that became the subject of this study. Based on pre observation, the researcher found that the lecturer produced code switching when he taught a lesson.

There were several steps in analyzing the data. First, after collecting the data, the researcher transcribed the data into written form in order to make it easy analyze the data. Second, the researcher deleting the data which was not supported the object that being observed. The researcher only selected the data that indicated code switching. Third, after reducing the data, the researcher classified the data based on the types and function of code switching based on theory of Myers-Scotton and Olmedo Williams. Fourth, the percentage of each type and function of code switching were measured by calculate the occurrence frequency of code switching. Fifth, after all of the steps above completed, the researcher concluded result of the study in form of table, chart, and description which provided by some examples.

\section{FINDINGS AND DISCUSSION}

From the observations, the lecturer had produced 663 utterances and 257 of those utterances were categorized as code switching that was produced by English lecturer. Code switching that was produced by lecturer were in form of intra sentential and inter sentential. The calculation of each type of code switching was presented in the form of table.

Table 4.1.1 The occurrences of Each Type of Code Switching

\begin{tabular}{|c|c|c|c|}
\hline \multirow{2}{*}{ Types of Code Switching } & \multicolumn{3}{|c|}{ Occurrence } \\
\cline { 2 - 4 } & Number of Utterance & Data Calculation & In Percentage (\%) \\
\hline Intra Sentential Code Switching & 134 & $\frac{134}{257} \times 100 \%$ & $52 \%$ \\
\hline Inter Sentential Code Switching & & & \\
\hline & & $\frac{123}{257} \times 100 \%$ & $48 \%$ \\
\hline Total & & & \\
\hline
\end{tabular}

The Example of Intra-Sentential Code Switching:

L: Janganterpengaruhiklanyang maybe yes maybe no haha (Don't be influenced by advertisement which is maybe yes maybe no haha)

In the example, the lecturer switched his language from Indonesian to
English (e.gJanganterpengaruhiklan). The lecturer switched the language in context of social for the sake of humor. This kind of code switching was done by the lecturer in order to make the student felt relax for a little bit by gave a humor that was easily to understand using this kind of code switching.

The Example of Inter-Sentential Code Switching: 
L: So, I should have done what you said. Sayaseharusnyamelakukanapa yang kamusarankan.

Berartikankejadiannyaterjadi di masalampau (So, I should have done what you said. I should have done what you said. It means that the event happens in the past)

The example was an example of inter-sentential code switching. It was produced by the English lecturer when he was teaching about the use of 'should have' material. The lecturer switched the code to give a stress about the answer that he gave. The lecturer switched the code from English to Indonesian to make the student understand about the grammar that was used in the sentence and enable the students to identify whether the sentence was happened in the present or happened in the past. The lecturer switched the code from English to Indonesian in order to avoid the student confused about the grammar in the sentence.

From the data collection that had been done at second semester class of EED at Ganesha University, there were 257 utterances could be listed as code switching. There were seven functions occurred in the teaching and learning process. The calculation of each function of code switching was presented in the form of table.

\begin{tabular}{|c|c|c|c|}
\hline Function of Code Switching & \multicolumn{3}{|c|}{ Occurrence } \\
\cline { 2 - 4 } & Number of Utterance & Data Calculation & In Percentage (\%) \\
\hline Regulatory function & 8 & $\frac{8}{254} \times 100 \%$ & $3 \%$ \\
\hline Emphasis function & 74 & $\frac{74}{254} \times 100 \%$ & $29 \%$ \\
\hline Attention function & 29 & $\frac{29}{254} \times 100 \%$ & $12 \%$ \\
\hline Lexicalization function & 20 & $\frac{20}{254} \times 100 \%$ & $8 \%$ \\
\hline Clarification function & 91 & $\frac{91}{254} \times 100 \%$ & $36 \%$ \\
\hline Sociolinguistic play function & 8 & $\frac{8}{254} \times 100 \%$ & $3 \%$ \\
\hline Instruction function & 24 & $\frac{24}{254} \times 100 \%$ & $9 \%$ \\
\hline Total & 254 & & $100 \%$ \\
\hline
\end{tabular}

The example of Clarification Function:

$\mathrm{L}$ : Yes because the speed limit is 30 miles, but Catherine doing 50. Jadibatasankecepatannyaitu 30 miles tapiternyata Catherine sampai 50 (Yes because the speed limit is 30 miles, but Catherine doing 50 . So the speed limit is 30 miles but Catherine's speed limits actually reach 50 )
From the example, it could be seen that the lecturer switched his language from English to Indonesian in order to make sure all the students understood about the explanation. (e.g. Jadibatasankecepatannyaitu 30 miles 
tapiternyata Catherine sampai 50) This function occurred after the lecturer had finished explaining a concept. The example clearly showed that the lecturer changed his speech from English to Indonesian language in order to re explain the previous concept that had been explained.

Function:

The example of Lexicalization

L: Its tank itutangkinyagituya, was empty( Its tank means the tank, it was empty)

From this example the lecturer began his speech in English and then changed his speech into Indonesian to fulfill lexical need. Some of the students are confused about 'tank' word. The students think whether tank refers to transportation or other thing. The lecturer changed his speech into Indonesian so the student knew what is the tank word meant in the sentence.(e.g. Itutangkinyagituya).

Function :

The examples of Emphasis

L: So why it use that way instead of could we go to the beach now? Kenapamenggunakan can? (So why it use that way instead of could we go to the beach now? Why use Can?)

From the example, the lecturer asked his students in English language. The lecturer explained about the use of can and could in the learning process. The lecturer asked the students a question in English in order to make the student knew what expression (could) was used in the sentences. After that the lecturer emphasized his question by changing his speech into Indonesian. The lecturer changed his speech when he asked about student's knowledge toward the question. (e.g. Kenapamenggunakan can?). The lecturer switched the code to make the student understood about the question which was given by the lecturer so they

in the class by said the answer in a language that the student would find easy to understand. would know what was being discussed in the lesson and know what they had to do next.

The example of Attention Function:

L: Okeuntuk yang nomer 4kitaskip (Ok we will skip the number 4)

This was the example of attention function of code switching. The lecturer used both of Indonesian and English language in order to give command to his students. The lecturer said skip in order to make the student easily understand about the lecturer purpose and knew what to do next (e.gOkeuntuk yang nomer 4). The lecturer wanted to make the student able to identify his order and made the student did not stuck in the question so they could move to another question

Function:

The Example of Regulatory

$\mathrm{L}:$ What is perhaps in Indonesia?

$S$ :Mungkin

$\mathrm{L}$ :Yes it mean mungkin, berartidiakankurangbegitukuatjikadibandin gkandenganmust (Yes it means perhaps, So it is not stronger if we compared it with must)

In the example, the lecturer used English and Indonesian language in his speech. This example was called regulatory function of code switching. In this example, the lecturer explained about the differences between perhaps and must. He gave a question in English form about what was the meaning of perhaps in Indonesian and then the students answered it in Indonesian. Then the lecturer changed his speech into Indonesian to emphasize the student's answer.

(e.g. berartidiakankurangbegitukuatjikadibandin gkandenganmust.).The lecturer changed his speech from English to Bahasa in order to control the situation

The example of Sociolinguistic Play Function 
S: She mad at me yesterday. I meet her at Park. I could have hug her and told her my feeling

L: Could hug? I could have told her my feeling, kasiansekali (L: Could hug? I could have told her my feeling, poor you)

This example was called sociolinguistic play function of code switching. In this example, the lecturer made a respond to the example that student was made. The example and the respond related to the students' daily life and the responds that lecturer gave were easy to accept by the student. The lecturer said the speech in English and then switched it into Indonesian as a respond to the student's sentence. The speech that was changed into Indonesianwas easy to understand by the student and made the students able to imagine the event.(eg. kasiansekali). The respond were able to make a funny atmosphere because it related to the student daily life and made the student happy

\section{Function:}

The Example of Instruction

L: First make the original sentence, the mistakes are like this and the correction. Jaditolong di saat kalian menganalisissepertiitu yang harus kalian yang pikirkanituadalahmembuatkoreksi.( First make the original sentence, the mistakes are like this and the correction. So please while you analyzing the sentence you have to think about how to make a correction).

Those examples were called instruction function of code switching. This function appeared because of the students' need. Sometimes, the lesson was stopped to run because the students do not understand about a particular word meaning. So, the lecturer should change his speech to native language to explain a word or meaning.

They were intra sentential code switching $(37.15 \%)$ and inter sentential code
There were some reasons followed why the teacher used code switching as a communication strategy in teaching and learning process;(1) Talking about a Particular Topic, (2) Being Emphatic about Something, (3) Interjection, (4) Repetition used for Clarification, (5) Intention of Clarify the Speech Content for the Interlocutor, (6) Peparing the Student to Work in the Real Life, (7) Increasing Motivation in Learning English, (8) Helping Students to Catch the Information that given from the Teacher, (9) Creating a Fun Learning Atmosphere, and (10) Giving command or instruction.

From those results of the study the most frequently used type of code switching used by English teacher was intra-sentential code switching (52\%). The second type was inter sentential code switching (48\%). The result of this study was supported by the theory of MyersScotton (1993), there were two types of code switching which were found in this research, such as intra sentential code switching and inter sentential code switching. The first, Intra sentential code switching was a simple change. The occurrence of this type was in a single word, phrase, or clause, without changing the basis language. This type was most frequently used by the English teacher in teaching and learning process. The second type was inter sentential code switching. This type occurred when the speaker changed his or her speech from one language to another language by changing the language basis. This switching occurred in the form of sentence level. This type was the second most frequently used by English teacher in delivering a material in the classroom.

This study was supported by the result of previous study that had been done by lqbal (2011), Pratiwi (2014) and Irwandika (2015). Based on the study which was conducted by lqbal (2011) at International Islamic University, he found there were two types of code switching that were produced by the lecturer

switching(3.66\%) which have parts in at word $(31.21 \%)$, clause $(21.54 \%)$, and phrase 
(6.42\%) level. In line, Pratiwi (2014) conducted study at SMK N 2 Singaraja. She found there were three types of code switching that were produced from three teachers. The most dominant type that used by English teacher at SMK N 2 Singaraja was intra sentential code switching (39.5\%), inter sentential code switching $(36.5 \%)$, and inter personal code switching (24.0\%). Irwandika (2015) got a result that intra sentential was the most type of code switching that was used by English teacher at SMK N 2 Seririt (61\%), inter sentential code switching (34\%), and interpersonal code switching (5\%).

In addition, Olmedo-Williams (1981), also supported the result of this study. $\mathrm{He}$ classified eight functions of code switching namely; regulatory function, emphasis function, attention function, lexicalization function, clarification function, sociolinguistic play function, addressee specification function and instruction function. But, in this research not all of the functions of code switching mentioned by Olmedo-Williams (1981) occurred. In this research there were seven functions; regulatory functions, emphasis function, attention function, lexicalization function, clarification function, sociolinguistic play function and instruction function.Addressee specification function was the only one function which not occurred in

\section{CONCLUSION AND SUGGESTION}

There were two types of code switching that was used by English lecturer at second semester of English Education Department at Ganesha University of Education. The most dominant type used by English lecturer was intra-sentential code switching (52\%) and the second one was inter-sentential code switching (48\%).

There were seven functions of code switching used by English lecturer in second semester of English Education Department at Ganesha University. The Themost dominant function of code switching used by English lecturer was clarification functions (36\%), emphasis function (29\%), attention function (12\%), instructionfunction (9\%), lexicalization function (8\%), then both regulatory function $(3 \%)$ and sociolinguistic play function (3\%) There were eight reasons of using code this research. This function did not occur because the lecturer had higher position in the classroom compared with all students. So, the lecturer never used this function to change his speech in teaching and learning process.

Moreover, Hoffman (1991), classified seven reasons why people used code switching in the conversation. These are seven reasons why lecturer is used code switching; (1) talking about a particular topic, (2) quoting somebody else, (3) being emphatic about something, (4) interjection, (5) repetition used for clarification, (6) intention of clarify the speech content for the interlocutor, and (7) expressing group identity. In this research, the researcher only found 4 reasons that matched with Hoffman's theory; (1) talking about a particular topic, (2) being emphatic about something, (3) repetition used for clarification, and (4) intention of clarify the speech content for the interlocutor. But, there were three reasons that did not appear in this research; interjection, quoting somebody else and expressing group identity. In addition, the researcher found 4 additional reasons based on the field observation and lecturer's interview; (1) increasing motivation in learning English, (2) helping students to catch the information that was given from the lecturer, (3) creating a fun learning atmosphere, and (4) giving command or instruction.

switching by English lecturer at second semester of English Education Department (1) talking about a particular topic, (2) being emphatic about something, (3) repetition used for clarification, (4) intention of clarify the speech content for the interlocutor, (5) increasing motivation in learning English, (6) helping students to catch the information that was given from the lecturer, (7) creating a fun learning atmosphere, and (8) giving command or instruction.

After concluding the finding of the study, the lecturer is suggested to use code switching as wisely as possible, because if they are used too much, the students will not learn, think and speak in English. In addition, it will make students become lazy to open the dictionary, because theyare accustomed to wait the lecturer translation. The use of code switching depends on the situation in the class.

For the further researchers are suggested for discuss other code switching phenomena. There are so manyphenomena of code switching that may occur in learning 
process. This is the first research about the code switching that is used by the lecturer. The further researcher may conduct a research about code switching used by lecturer in other university and learn about the phenomenon of code switching that may occur there

\section{REFERENCES}

Ariffin and Husin, 2011. Code-switching and Code-mixing of English and Bahasa Malaysia in ContentBased Classrooms: Frequency and Attitude. Voll 5 issues 1 Retrieved fromhttp://www.linguisticsjournal.com/2011-index/11index/2011/42-code-switching-andcode-mixing-of-english-andbahasa-malaysia-in-contentbased-classrooms-frequency-andattitudes

Cook, V., 2000.Second language learning and language teaching. Beijing: Edward Arnold Limited

Hoffman, C. 1991. An Introduction to Bilingualism. New York: Longman Press. Retrived from https://books.google.co.id/books?h $l=i d \& \mid r=\& i d=L 3 J 3 v N T O z W A C \& o i=f$ $n d \& p g=P A 143 \& d q=$ Hoffman,$+C .+$ 1991. + An+Introduction+to+Bilingu alism.+New+York:+Longman+Pres $s \& o t s=R w K o D 8 W X 8 B \& s i g=T-$ 1RqoXIEEkOTKfb YPcgYJPzZ4\&redir_esc $=y \# v=o n$ epage\&q\&f=false

Husna,Itaul.2010. Code Mixing and Code switching in KetikaCintaBertasbih I novel. Study program of English, University of Brawijaya.

lqbal, 2011, Linguistic Features of CodeSwitching: A Study of Urdu/English Bilingual Teachers' Classroom Interactions. International Journal of Humanities and Social Science .Vol1 no 14 Retrieved from www.ijhssnet.com/journals/Vol 1 No 14 October 2011/26.pdf
Irwandika, G (2015). A Study of Code Switching Used By English Teacher As Communication Strategy In Teaching English As A Foreign Language At SMK N 2 Seririt In Academic Year 2014/2015.

Jingxia, L. (2010). Teachers CodeSwitching to the $L 1$ in EFL Classroom. The Open Applied Linguistics Journal, 3, 10-23.

Kebeya, Hilda (2013), Inter- and IntraSentential Switching: Are they really Comparable?.International Journal of Humanities and Social Science. Vol. 3 No. 5; March 2013

Ling, 2013, Influence of An English Lectuter's Code Switching practice on Students Confidence in the Subject. International Journal of Asian Social Science.Voll 4(2) Retrieved fromhttp://www.aessweb.com/dow nload.php?id=2635

Lucachristiani,2013,

PengertianDosen.Retrieved from https://lucakristiani.wordpress.com/ 2013/06/19/pengertian-dosen/

Mati, Xola. 2008. Using Code Switching as a Strategy for Bilingual Education in the Classroom. AEAA Conference

Myers-Scotton, C. $\quad$ 1993. Contact Linguistics: Bilingual Encounters and Grammatical Outcomes.Oxford University Press

Olmedo-Williams, L. 1981. Functions of Code Switching in a Spanish/English Bilingual Classroom.Paper presented at the first Delaware Symposium on Language Studies. Available at https://scholarwork.wmich.edu/pdf

Pratiwi, D. 2014. A Study on the Use of Code Switching as a Communicative Teaching Strategy by The English 
Teachers at SMK Negeri 2 Singaraja in the Academic Year 2013/2014.

Sert. 2005. Code-switching in the Foreign Language Classroom.www.diva-portal.org

Soodeh, Adlina, and Elham, 2012, Code Switching as a Medium of Instruction in an EFL Classroom.Voll.2 no.11. Retrieved from

http://ojs.academypublisher.com/in dex.php/tpls/article/view/tpls02112 $\underline{2192225}$

Then, David,2011, Researching Code Switching in the Teacher Classroom Discourse. The international Journal_Language
Society and Culture. Voll.33 Retrieved from www.aaref.com.au/attachment.asp $\underline{x ? i d=1989}$

Teik and Lian,2013, A preliminary study of teacher code switching in Islamic education instructions. The International Journal_Language society and Culture.Retrieved fromwww.melta.org.my/ET/2013/o ng\%20chew.pd

Wardaugh. 1998.Linguistic Features of Code-Switching: A Study of Urdu/English Bilingual Teachers' Classroom Interactions. International Journal of Humanities and Social Science Vol. 1 No. 14; October 2011 